\title{
Cartas Persas: \\ passado e presente
}

MARIA ODILALEITE DA SILVADIAS

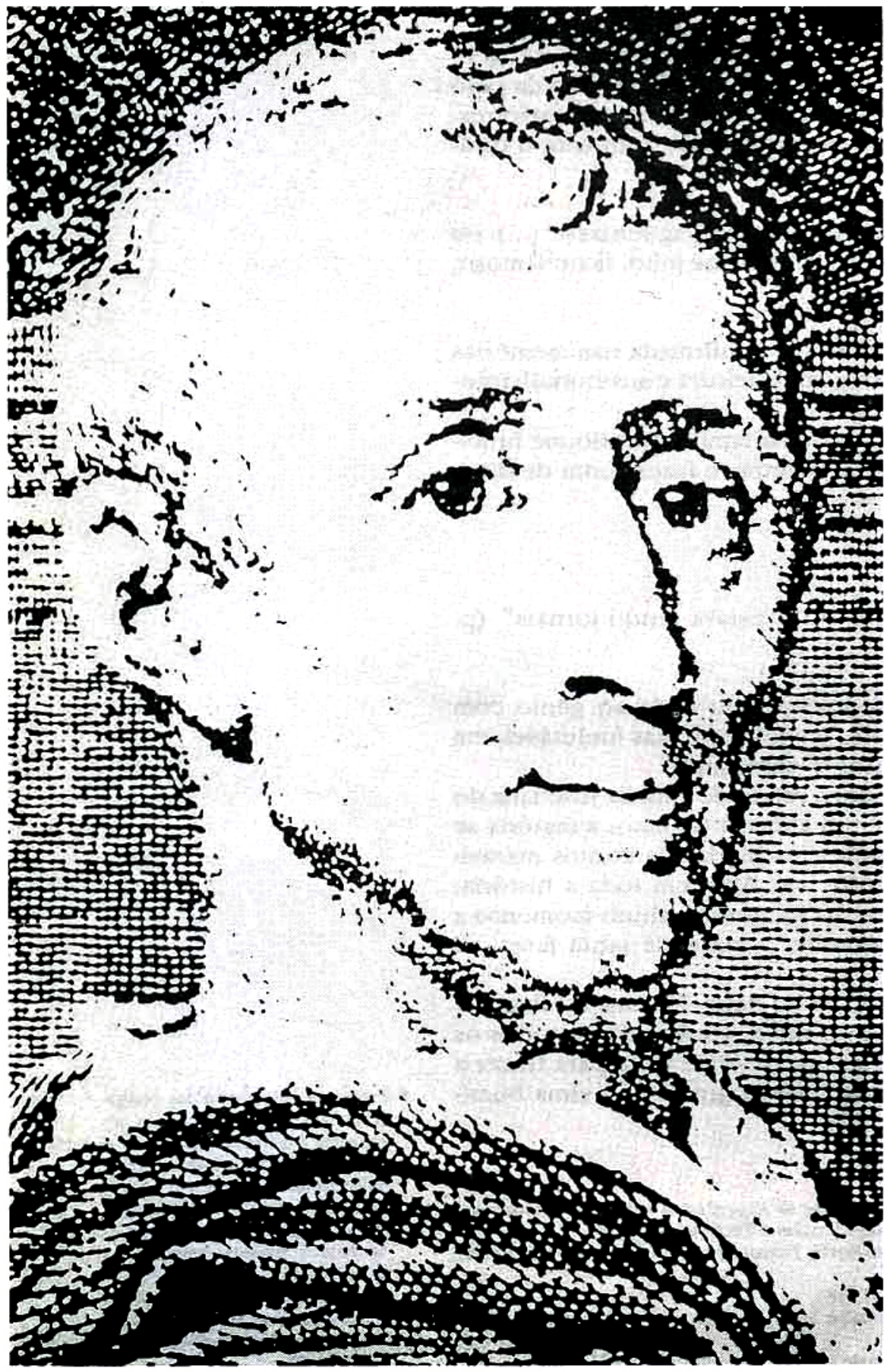

É enriquecedora a oportunidade de ler na tradução cuidada e elegante de Renato Janine Ribeiro uma obra importante de Montesquieu, publicada em Genebra em 1721, que nos põe em contato com o próprio processo de formação da modernidade crítica dos ilustrados e ainda nos oferece a possibilidade de refletir sobre as pontes que nos separam e nos projetam, tal como nos pensamos hoje, ao modo dos franceses se refletirem no momento histórico representado pelas Cartas Persas. Sob a forma de um romance satírico, construído através da correspondência de múltiplos personagens, os pontos de vista individuais se entrecruzam sob uma multiplicidade de assuntos, que podem ser abordados sem ordem nem plano e que todos pōem em discussāo problemas importantes, costumes, leis, moral, política, o individual, o público e o interesse geral, de modo que se entrecruzam e completam num feixe de perspectivismos e de criticas ferinas à França da Regência de Luís XV e dela se estendendo até nós, por somarem com estilo e método, uma cadeia de particularidades em busca de sentidos globais, que o estilo do escritor torna acessível à sensibilidade do leitor e nāo apenas compreensível à razão. "Mesmo nos menores detalhes há algo singular que posso sentir, mas nāo consigo expressar" (p. 47), diria a respeito da busca da forma para moldar sua obra, pois para Montesquieu nāo bastava persuadir, era preciso, além disso, fazer o leitor sentir (p. 29): "Todo o agrado desta obra só podia consistir no eterno contraste entre as coisas reais e a maneira singular, nova ou estranha, pela qual elas eram percebidas" (p. 265).

As Cartas Persas enquanto romance epistolar evocam um processo de civilizaçāo, de difusão de modos críticos de pensar capazes de transcenderem a Igreja, a Tradiçäo, sem romper com o passado, a continuidade histórica, de modo que pro- 
fundas reformas são descortinadas através de um método de pensamento e de um modo de exprimi-las, que permitem o proselitismo ameno e suscitam sutilmente o debate. Trata-se da busca de verdades e de suas legitimidades, desde pequenos hábitos de todo o dia - a urbanização, as relaçōes entre os sexos, o divórcio, duelos, a moda - até as leis fundamentais da nação, autoridade do Rei e seus limites, o papel dos nobres, dos burgueses em ascensão social, das várias formas de justiça e de governo, da sociedade, enfim, da humanidade.

Descendente de uma família enobrecida na carreira militar desde o século XVI, nascido em 1689 nas proximidades de Bordeaux, Montesquieu teve uma formação apurada, na escola dos oratorianos, perto de Paris. Em 1716, aos 27 anos, já advogado conhecido, formado em 1708 pela Universidade de Bordeaux, com oito anos de prática em Paris, Montesquieu herdou de um tio o título de barão e o cargo de presidente do Parlamento de Bordeaux. $A$ experiência de magistrado engajado na luta política da aristocracia de província, a vida social mundana nos salões mais requintados de Paris, onde se destacava enquanto intelectual por sua aparente distração e humor irônico, levaram-no a iniciar sua vida de escritor marcado pela perspectiva destes mundos diferentes nos quais circulava e que através da sátira que. ria de certa forma escrutinar e transcender. "Educo-me nos segredos do comércio, nos interesses dos príncipes, na forma do governo local" - escrevia Rédi a Usbek. "Não me descuido sequer das superstições européias: dedico-me à medicina, à física, à astronomia: estudo as artes; em suma, saio das nuvens que me embaçavam os olhos no país em que nasci". (p. 60).

A escolha do romance epistolar calhava bem com seu feitio de intelectual ilustra- do. Estava então muito na moda, como bem lembra o tradutor em sua introdução. Na verdade, Montesquieu parodiava certas Cartas Siamesas (1707), publicadas por Dufresny, obra que ele provavelmente leu, quando ainda terminava o curso secundário. Na obra de Montesquieu, a sátira viria delicada e espirituosamente velada por um estilo decisivamente marcado por $\mathrm{La}$ Bruyère, elegante, lapidado, severo, evitando a todo custo o pomposo e o grotesco. Como ele mesmo escrevia, preferia o coloquial e o quotidiano. O seu estilo de escrever, principalmente na obra em questão, expressa justamente um processo de sociabilidade, um modo de conviver em sociedade, que soube transformar em debate, em diálogo, em convívio intelectual mundano, ameno, prazeroso; questōes candentes como a pobreza, a mortalidade infantil, o aborto, as intrigas da Corte, o poder do Rei, a moda, as mulheres em sociedade, mobilidade social, nouveaux $\mathrm{r}$. ches, educação, justiça, o cumprimento de leis. Buscava captar a diversidade com que se expressava a natureza humana e fugir de uma linguagem neutra ou uníssona (p. 110).

A publicação das Cartas Persas reforça de certa maneira a interpretação de Peter Gay (1) do processo de desenvolvimento da Ilustração como sendo sobretudo um processo de difusão mais do que o de produçāo de idéias liberais, iconoclastas e reformadoras da sociedade. Neste sentido a forma da obra de Montesquieu merece um devido destaque, pois realça o processo de divulgação ameno e divertido de idéias fundamentais sobre a própria natureza da sociedade, porém difundidas nos salōes aristocráticos sob uma forma de sociabilidade de elite essencialmente urbana. A conversação e o provocar de debates como que forçando o exercício do espírito crítico, despertando a consciência social e forçando ao vivo o proselitismo, a difusão
MARIA ODILA LEITE DA SILVA DIAS é professora titular de História do Brasil do Departamento de História da FFLCH-USP.

Cartas Persas, Charles de Secondat

Montesquieu, traduçāo de Renato Janine

Ribeiro, Sāo Paulo,

Paulicéia, 1991, 265 pp.

1 Peter Gay, The Enlighten ment: an Interpretation. v.II. The Science of Fre edom, New York, A. Knopf, 1969, pp. 324-5. 
e propagação de um modo crítico de rever a experiência da vida em sociedade.

Com aguda sensibilidade, Montesquieu voltava-se para o estudo das ciências úteis e para a metafísica, com enfoque essencialmente político como caberia ao perfil do intelectual da Ilustração; insistia na necessidade de exercitar a razão, de descobrir as leis que regem a natureza humana através da experiência, superando dogmas, tradiçōes, vícios e preconceitos atávicos. Feudal inimigo do despotismo, escreveu a respeito dele Louis Althusser, encontrou no passado as chaves para o futuro (2).

Aristocrata e homem de elite, discípulo de Montaigne e de La Bruyère, era ao mesmo tempo um indivíduo combativo e sofrido: "No curso de uma longa vi$\mathrm{da} "$ - diria o primeiro eunuco na carta a Ibbi -, " nāo posso afirmar que tenha tido um só dia sereno e um único momento tranqüilo" ... Em sua correspondência, observava que preferia "a tormenta do corpo à tormenta do espírito" . Crítico do seu próprio mundo e ainda identificado com a luta política da aristocracia, ao cultivar um convívio intelectual didático e ilustrador, tinha um projeto bastante concreto, de certa forma moralista. Sob os costumes decadentes, procurava discernir o melhor da natureza humana e traçar o perfil de suas leis fundamentais para mostrar como se relacionavam com as necessidades específicas de cada indivíduo, enquanto chefe de família, patriota, cidadão vinculando o mais banal e quotidiano às perspectivas de reforma da monarquia, da nação francesa e de toda a humanidade. "Si je savats quelque chose qui me fût utile et que fût préjudiciable à ma famille, je le rejetterais de mon esprit. Si je savais quelque chose qui fût utile à ma famille, et qui ne le fût pas à ma patrie, je chercherais à l'oublier. Si je savais quelque chose utile à ma patrie et que fût préjudiciable à l'Europe et au genre bumain, je le regarderais comme un crime."

Sob forma amena como atitude perante a vida, delineava nas Cartas Persas um programa de reformas políticas, cuja necessidade já se impunha a seu ver como inadiável. Montesquieu estava associado ao movimento aristocrático que pretendia reforçar a esfera de autoridade dos tribunais judiciários, dos parlamentos e cercear o direito divino do Rei. Argumentava em prol dos privilégios feudais, que contraditoriamente se confundiam em suas origens com a palavra liberdade, defendendo acima de tudo a liberdade do indivíduo em processo de se transformar em cidadão.

Resvalava neste sentido pelo pioneirismo radical de um pensamento em princípio reacionário, pois partia dos interesses históricos e da defesa dos privilégios e isençōes fiscais da aristocracia togada francesa contra a excessiva concentração de poder na esfera real ou do poder executivo. A crítica ao governo de Luís XIV e à perversidade de ministros, que voltavam o Rei contra a sua Corte e os seus vassalos (p. 205), ampliava-se para a crítica da Regência no início do reinado de Luís XV e desta para qualquer paroquialismo.

Participava na realidade de dois mundos. Enquanto presidente do Parlamento de Bordeaux, cargo herdado, defendia as prerrogativas da aristocracia e a separação dos poderes, com ênfase, é claro, na importância dos tribunais judiciários como eventuais autoridades capazes de equilibrar excessos do poder real ou do despotismo esclarecido. Nesse sentido, apoiava o movimento político da aristocracia, que se fortalecia contra o Rei tentando conservar prerrogativas judiciais, fiscais e administrativas. Como intelectual e aristocrata dos salöes parisienses, teve um papel pioneiro e de vanguarda na formaçăo da crítica liberal e na gestaçăo do movimento secular, reformista. "O tempo, que tudo consome, destruirá até os erros: todos os homens se surpreenderão ao se verem sob o mesmo estandarte; tudo, até a própria Lei, se terá consumado: os divinos exemplares serão retirados da Terra e levados aos arquivos celestiais" (p. 65).

A formação da intelectualidade ilustrada correspondia a um fenômeno tipica. mente parisiense e, pois, essencialmente urbano. Daniel Mornet (3) em seus estudos sobre as origens do pensamento ilustrado também ressaltou o papel da intelectualidade urbana e dos processos de sociabilidade gerados no correr das primeiras décadas do século XVIII: as sociedades literárias e científicas, os salōes, depois as lojas maçônicas (Montesquieu fazia parte de uma), os círculos de palestras e conferências, finalmente os cafés, enfim o hábito da conversação e do debate de temas polêmicos relativos às necessárias reformas políticas, religiosas, educacionais, econômicas, culturais, que faziam parte de um processo histórico bem mais amplo, explicam também a forma acessível, relativamente desordenada, em que os temas tuelles de la Révolution Franç Paris, 1933; Ira Wade, The Intellectual Origins of the French Enlight tenment, Princeton, Princeton Univ. Press, 1971; Roger Chartier. A História Cultural entre Práticas e Representaçóes, trad. de Maria Manuela Galhardo, Lisboa, Difel, 1990.

Louis Althusser, Montesquieu. La Politique et I'Histoire, Paris, 1959. são apresentados por Montesquieu, nas Cartas Persas. 
A publicação desta obra em 1721 suscitou polêmicas, intrigas, inimizades, problemas sérios com a Igreja e, ao mesmo tempo, um grande sucesso mundano nos salões de Paris, de modo que intensificou sua vida intelectual e social. Aproximou-o do salão de Mme. Lambert, que o levaria até a Academia Francesa. Muito da diversidade de interesses e da amplitude de suas preocupações marca esta primeira obra, que anuncia as obras posteriores. As discussões mais profundas acerca da ambígua e sutil distinção das esferas públicas e privadas dão muito o que pensar sobre a cultura ilustrada e o perfil do homem de letras na primeira metade do século XVIII. $\mathrm{O}$ indivíduo transcendia paróquia, pátria, para situar-se no mundo. "Como se o direito público não fosse também ele um direito civil, não, é claro, de um país em particular, mas do mundo inteiro" (p. 157). Era o que reiterava em inúmeras passagens dessa sua primeira obra: "O coração é cidadão de todos os países. Como uma alma bem feita poderá impedir-se de contrair laços?... Assim sou eu, Usbek: onde quer que encontre seres humanos, formarei amigos" (p. 115).

Um grande espaço do livro, provavelmente também de sua vida pessoal, é dedicado ao assunto das relaçōes amorosas e de poder entre homens e mulheres. Montesquieu politiza o sexo e sensibiliza as artes eróticas através de cartas em que expõe as manhas do serralho; o domínio exercido por um e outro sexo, as ambigüidades do prazer e da sedução, as qualidades da sensibilidade e da natureza, trabalhadas com sutileza para exercerem o almejado poder. Cerca de um quarto do livro consiste na correspondência privada de Usbek, com os eunucos, com suas mulheres Zachi, Fatmé, Zéfis e delas com ele. Muito do mundo dos libertinos transparece das críticas ao serralho persa e sobretudo às artimanhas de poder de mulheres aparentemente submissas. "O amor entre nós", escreve Usbek a Ibben (carta 56), " não causa perturbação nem furor; é uma paixão debilitada, que traz calma à alma: a poligamia liberta-nos do império das mulheres, ao mesmo tempo que modera a veemência dos nossos desejos" (pp. 99-100). Na França, "um marido que pretendesse ser o único a possuir sua mulher seria tido como um perturbador da ordem pública, como um insensato que almejasse gozar da luz do sol em detrimento dos outros homens" (p. 98).

Na carta 107 documenta o enorme poder político exercido informalmente nos bastidores e nos salóes pelas mulheres francesas, que chegavam praticamente a controlar um estado dentro do Estado. Na Pérsia era notória a influência de duas ou três mulheres junto ao Déspota, porém, na França, todas as mulheres mandavam, e não apenas no atacado, mas também no varejo (p. 178). Ao mesmo tempo, Montesquieu coloca na ordem do dia muitas das questôes levantadas pelas feministas do século XVII, como se divulgasse o Tratado da Moral e da Política: a Liberdade - publicado por Gabriela Suchon, em 1693 (4) . A questão entre os sexos consistia numa luta pelo poder com armas muito desiguais. As mulheres apelando para a sedução, os homens para a autoridade. "Se recebessem a mesma educação, suas forças se igualariam às nossas" (p. 70). "Parece que a natureza, depois de criar as mulheres dependentes, deu-lhes a liberdade. Nasceu a desordem entre os dois sexos, porque ambos tinham direitos" (p. 46). Defendia abertamente o divórcio: "Nada contribuía mais para a afeição recíproca do que a possibilidade do divórcio", pois entāo o casamento levaria em conta o prazer dos sentidos (p. 190). Em carta a seu marido Usbek, escrevia Zéfis sobre a sua condição de mulher sem liberdade, aprisionada pelos eunucos, porém na sua prisão paradoxalmente mais livre do que o sultāo: " Eu vivi, enquanto tu apenas vegetavas... Sempre que aumentares os cuidados com que me guardas, mais me farás gozar de teus temores e tuas suspeitas, teu ciúme, teus medos são outros tantos sinais de tua dependência" (p. 109).

$O$ pano de fundo do que escreve Montesquieu acena para a diversidade e mutabilidade da natureza humana "que se exprime das maneiras mais diversas e aparece sob uma variedade de formas". "Os viajantes procuram sempre as grandes cidades, que são uma espécie de pátria comum a todos os estrangeiros" (p. 47).

A Religião e as Leis deveriam adequar-se à natureza infinitamente complexa dos seres humanos e a sua sensibilidade movediça, que ousava desvendar na primeira metade do século XVIII. " Parece que a natureza dos prazeres consiste em serem eles sempre de curta duração: a imaginação sente dificuldade em representar outros" (p. 203). A sua trajetória de libertino - livre-pensador e livre gozador - o levaria a freqüentar em Paris uma variedade grande de mulheres e a amar inúmeras. Em 1725, quatro anos após a publicação das Cartas Persas, escreveria um livro sobre o erotismo dedicado à Princesa de Clermont, intitulado Templo de Gnida. Por

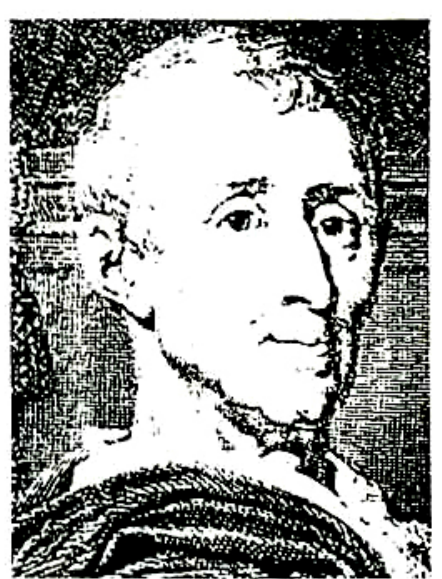

4 Séverine Auffret, ed. Gabrielle Suchon, Traité de la Morale et de la Politique. La Liberté (1693), Paris, Éditions des Femmes, 1988; $G$. Thibault Laurent, La Première Introduction du Divorce en France sous la Révolution of l'Empire. Thèse de Doctorat, Montpéllier. 1938; Joan Kelly, Early Feminist Theory and the Querelle des Femmes, Signs, 8, n.1. 1982, pp. 4-28; lan MacLean. Woman Triumphant: Feminism in French Literature, 1610-1652. Oxford, Oxford Univ. Press, 1977; Katherine B. Clinton. "Femme et Philosophie: Enlightenment Origins of Feminism", in Eighteenth Century Studies, n. 8, 1974-5, pp. 283-99; Evelyn Gordon Bodek. "Salonieères and Bluestockings: Educated Obsolescence and Germinating Feminism", in Feminist Studies, n. 3, 1976, pp. 185-99; Samia I. Spencer, ed. French Women and the Age of Enlightenment, Bloomington, Indiana Univ.Press, 1984; Martine Sonnet, L'Éducation des Filles au Temps des Lumières, $\mathrm{Pa}$ ris, Le Cerf, 1987; Joan Landes, Women and the Public Sphere in the Age of the French Revolution, Ithaca, Cornell Univ.Press, 1988; Paule Marie Duhet, Las Mujeres y la Revolucion 1789-1794, Barcelona, Ed. Peninsula, 1974. 
esta época, esboçou também um "Ensaio sobre o Gosto", no qual se aventurava a escrever com aguda sensibilidade sobre a beleza e a estética e que publicaria vinte e cinco anos depois na Grande Enciclopédia de Diderot e D'Alembert.

Polêmico e provocador, o autor das Cartas Persas já prenunciava nesta primeira obra a trajetória intelectual que o levaria a ocupar um dos mais eminentes lugares entre os pioneiros da modernidade. Com a originalidade de sua vocaçāo filos 6 fica $e$ teórica, irreverente e bem-humorado, resvalou por assuntos vitais. Nas Cartas abordou corajosamente temas delicados como o da necessidade de convívio entre muitas religiōes: "Um homem rezava a Deus, todos os dias, esta prece: ' Senhor, nada entendo de tudo o que se polemiza a vosso respeito. Bem vos desejaria servir segundo a vossa vontade, mas cada um a quem consulto quer que eu vos sirva ao gosto dele. Quando quero dizer-vos minha prece, não sei em que língua devo falar. Näo sei sequer que postura devo ter: um diz que o correto é ficar de pé, outro que devo me sentar, um terceiro exige que meu corpo se apóie nos joelhos. E não basta isso: há quem pretenda que todas as manhãs me deveria lavar com água fria; outros sustentam que vós me tereis em horror se eu não me fizer cortar um pedacinho de carne' " (p. 79). Ousou entrar em conflito com a Igreja Católica, defendendo abertamente, ainda quando fervia a questāo com os jansenistas, a conveniência da tolerância religiosa: "Pode-se notar que quem professa uma religião tolerada costuma tornar-se mais útil a sua pátria do que quem pertence à religião dominante: isso porque, afastado das honrarias, sర podendo se distinguir por sua opulência e riquezas, a única forma pela qual ele pode adquirir alguma coisa é trabalhando, e abraçando os empregos mais penosos da sociedade" (p. 145). Criticou outros aspectos da Igreja Católica, como a Inquisiçāo, as dispensas e o próprio dogma da providência divina, quando expõe o princípio do livre-arbítrio dos homens como parte da natureza humana. Deus foi capaz de criar, mas delegou ao homem a escolha entre o bem e o mal e a responsabilidade por suas próprias açōes. "A alma é artífice de sua própria determinação, mas há ocasiōes em que está indeterminada a tal ponto que nem mesmo sabe para que lado se determinar. Certas vezes, por sinal, ela somente se decide para usar de sua liberdade; de maneira que Deus não pode ver essa determinação previamente, nem na ação da alma nem na ação que os objetos exercem sobre ela" (p. 125).

Arcaria com as conseqüências de sua opinião, enfrentando a perseguição da Igreja por ocasião da publicação de sua obra maior O Espirito das Leis, que foi indexada em $1750 \mathrm{e}$, ainda no momento de sua morte, em 1755, quando resistiu às pressões do Bispo para que publicasse um desmentido às Cartas Persas, a que se recusou terminantemente. Em 1721, quando ainda trabalhava intensamente como magistrado, teve a coragem de publicá-las num estado de espírito revelador de sua ousadia espiritual: "Tudo me interessa, tudo me assombra: sou como uma criança a cujos órgãos ainda tenros os menores objetos continuam sendo capazes de marcar intensamente" (p. 82). Irreverente e provocador, definia-se antes livre-pensador do que propriamente religioso praticante: "Acredito na imortalidade da alma conforme o semestre. Minhas opiniōes dependem por completo de minha constituição física: segundo eu tenha espíritos animais em número maior ou menor, meu estômago faça a digestão bem ou mal, o ar que respiro seja de boa ou má qualidade, as carnes de que me alimento sejam leves ou pesadas, serei espinosiano, socianiano, católico, ímpio ou devoto. Quando o médico está ao pé de minha cama, é o melhor momento para o confessor. Sou perfeitamente capaz de impedir a religião de me afligir quando estou bem de saúde; mas autorizo-a a me consolar assim que adoeço. Quando nada mais tenho a esperar por um lado, a religiảo se apresenta e me conquista por meio de suas promessas: aceito de bom grado confiar-me a ela e morrer no seio da esperança" (p. 131).

As Cartas Persas vão da sátira à ciência política, da filosofia do conhecimento à história, da literatura de salão e dos exempla (Cartas, 12, 67, 141) ao tratado sobre o espírito das leis e aos próprios fundamentos das ciências sociais, da demografia, da antropologia, da sociologia e do direito - bem no espírito civilizador e polêmico dos filosofos ilustrados, de que esse seu primeiro livro foi uma das mais influentes obras de propaganda. Sentia necessidade de denunciar problemas sociais, de detectá-los, indicar os males mais imediatos que atribulavam a sociedade francesa e ainda de alcançar suas extensões mais amplas e globais. " "Tranqüilos quanto à vida presente, despreocupados quanto à futura, não cuidamos nem de consertar os edifícos públicos, nem de conquistar para a lavoura as terras incultas, nem de cultivar as que 
podem receber nosso trabalho: vivemos numa insensibilidade completa, e deixamos em mãos da Providência tudo o que resta por fazer" (p. 194). Neste sentido, a sua primeira obra foi um prenúncio eficiente das alturas que alcançaria em obras posteriores.

As Cartas Persas documentam as tensões do processo de urbanização e de crescimento econômico instável porque passavam os franceses na Regência do Duque de Orleans, após a morte de Luís XIV. Apesar de membro da aristocracia togada, Montesquieu tem palavras duras para com a decadência dos parlamentos, pelos quais gostaria de lutar e cujo papel político o inspirou a enunciar a teoria da divisão dos poderes. Acreditava que a venalidade dos cargos, que se vendiam e trocavam, garantia certa independência do judiciário, que acabava por ser um meio eficaz de controlar os excessos do despotismo real. Lamentava, porém, os defeitos e vícios dos nobres e a crise por que passavam em seu tempo: "Essas grandes corporaçōes cumpriram o destino das coisas humanas: cederam ao tempo, que tudo destrói, à corrupção dos costumes, que tudo debilitou, à autoridade suprema, que tudo derrubou" (p. 154). Gostaria de ver ressaltada a independência da nobreza judiciária, porém não poupou críticas ao seu próprio meio social. Refere-se à falta de educação e de grandeza de espírito dos nobres, justamente os que mais deveriam contribuir para regenerar os males que ameaçavam de decadência os franceses (p. 83).

Critica a ascensão social dos burgueses e dos novos-ricos, cujo oportunismo acentuava os vícios do poder real, o favoritismo, a corrupção política. "Os lacaios que fizeram fortuna no reinado passado hoje se gabam de seu nascimento; voltam contra os que acabam de largar a libré, numa determinada rua, todo o desprezo com que eram tratados havia apenas meio ano; gritam com todas as forças: Está arruinada a nobreza!... Mas te asseguro que os novos logo se desforrarão nos que vierem depois deles, e que dentro de uns trinta anos todos estes fidalgos farāo bastante ruído" (p. 226; cf. também pp. 163-4).

Durante o reinado de Luís XIV, os burgueses tinham se insinuado nos cargos de ministros e de intendentes da Corte (5). Na época de Montesquieu, entretanto, durante todo o século XVIII até as vésperas da Revolução, houve tenaz resistência dos nobres, que se apegaram aos privilégios de seu estado para retomar o monopólio dos cargos administrativos e judiciários.

Montesquieu, por motivos pessoais, desistiria de seu cargo de presidente do Parlamento e o revenderia em 1726. Casado com Jeanne de Lartigue, senhora protestante bastante rica e com apurado senso dos negócios, confiou a ela a administração de suas terras em La Brède, dedicando-se inteiramente à vida de intelectual urbano e às lidas nos salōes de Mme. Alembert, em Paris, que lhe abriria finalmente as portas da Academia Francesa.

Nem por participar da vida intelectual urbana e por conviver estreitamente com burgueses intelectuais ou negociantes citadinos (6), deixaria o espírito crítico de Montesquieu de apontar os males mais graves que a seu ver entorpeciam a França. Dentre estes o oportunismo político, o favoritismo real e a instabilidade das grandes fortunas burguesas formadas antes por especulação financeira do que por investimentos no comércio ou na indústria, agravadas pelo desvario da política econômica de John Law.

Admirador do processo comercial e industrial dos ingleses, identificava-se com o crescimento urbano. Admirava a sede de riqueza que se apoderava de todos os burgueses, artesãos, nobres e os forçava a acumular capitais sem limites, procurando sempre mais e mais. "Paris talvez seja a cidade mais sensual do mundo, aquela onde os prazeres encontram seu maior requinte; mas talvez em nenhuma a vida seja tão dura. Para que alguém viva nas delícias, é preciso que cem outros trabalhem sem sossego. Uma mulher decide ir a uma reunião vestida de tal forma: deste momento em diante, é necessário que cinqüenta artesãos não durmam, não tenham folga nem mesmo para comer e beber: ela manda e é obedecida com mais presteza que nosso próprio monarca, porque o interesse é o maior monarca da Terra. Este ardor pelo trabalho e essa paixão de enriquecer-se se transmitem de condiçāo a condiçāo, desde os artesāos até os grandes do reino" (p. 175).

A especulação desenfreada, a corrupção e a instabilidade política eram obstáculos imediatos à prosperidade dos franceses. Sucediam-se ministros e planos financeiros sem atinarem com o remédio para os males econômicos que agiam no organismo da nação. " É preciso que grandes gênios trabalhem noite e dia, que dêem à luz sem cessar e com enorme dor novos projetos; que escutem a opinião de uma

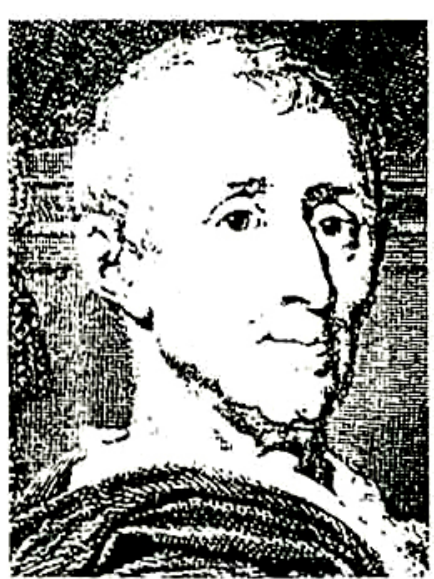

5 A. Soboul, La Civilization et la Ré volution Française, Paris. Arthaud. 1970. pp. 239 e segs.

6 Hémery, o espiảo encarregado de vigiar os escritores em Paris, anotava no seu livro (1748.53) a proporção de intelectuais provindos dos diferentes estados: $17 \%$ eram nobres, $12 \%$ clérigos, $70 \%$ burgueses. Montesquieu e Voltaire eram os mais velhos, únicos testemunhos do reinado de Luís XIV. Os demais muito jovens por volta de 1750, ano em que acompanhava atentamente a publicação do Es. pirito das Leis de Montesquieu como livro bastante subversivo. Robert Darnton, O Grande Massacre dos Gatos e Outros Episódios da História Cultural Francesa, Rio de Janeiro, Graal, 1986, pp. 192, 195. 198. 
infinidade de homens que trabalham para eles sem terem sido solicitados; que se retirem e vivam no fundo de um gabinete indevassável aos grandes e sagrados para os pequenos; que tenham sempre a cabeça repleta de segredos importantes, de propósitos mirabolantes, de sistemas novos, e que de tão absorvidos em suas reflexões acabem privados do uso da palavra e às vezes até mesmo da polidez" (p. 225).

Montesquieu criticou acerbamente o ministro John Law e seu plano monetário que fazia e desfazia fortunas de um dia para o outro. "Todos os que eram ricos há seis meses hoje estão reduzidos à pobreza e quem não tinha pão agora regurgita de riquezas. Nunca esses dois extremos estiveram tão próximos... Que fortunas inesperadas, inacreditáveis até para quem as fez! Deus não foi mais rápido ao tirar os homens do nada. Quantos criados servidos hoje por seus colegas, e amanhā, talvez, por seus amos! Subversão cabal dos princípios da lei e da justiça eram os primeiros resultados de tamanha instabilidade social e financeira. (...) invocavam leis odiosas para justificar as açōes mais covardes, e davam o nome de necessidade à injustiça e à perfídia. Vi ser desrespeitada a fé dos contratos, desprezadas as mais sagradas convençōes, violadas todas as leis da família. Vi devedores avarentos - orgulhosos de sua insolente pobreza, instrumentos indignos de fúria das leis e do rigor dos tempos - fingirem pagar o que deviam, e assim enfiarem a faca no peito de seus benfeitores..." (p. 249). Não parece admirar muito a ascensão fácil dos novos-ricos ou a trajetória dos cobradores de imposto. "Em Paris, reinam a liberdade e a igualdade. $\mathrm{O}$ nascimento, a virtude, nem mesmo as mais brilhantes proezas militares, nada disso basta para salvar um homem da multidāo na qual se confunde. Nāo se conhece aqui a inveja das posiçōes. Simplesmente se diz que a primeira pessoa de Paris é a que tem os melhores cavalos atrelados a sua carruagem" (p. 149). Escreveu fràses ferinas acerca de burgueses recém-enriquecidos: "O corpo dos lacaios é mais respeitado na França que nos demais países; é um seminário de grandes senhores: preenche o vazio dos outros estados, seus integrantes ocupam o lugar dos grandes que caem em desgraça, dos magistrados falidos, dos fidalgos mortos no furor da guerra; e, quando seu número já não se mostra suficiente para suceder a tanta gente, reerguem as grandes famílias por meio de suas filhas, que são como uma espécie de esterco a fertilizar um solo montanhoso e árido" (pp. 163-4).

Males mais prementes tais como a decadência da população, o despovoamento, as fortunas predatórias, a diminuição da circulação da moeda, do comércio, das artes, das manufaturas (p. 193) são atribuídos por Montesquieu a causas mais profundas, entre as quais certo desequilíbrio entre o despotismo e a liberdade dos súditos, a inadequação das leis aos costumes, ao clima, à sociedade, a sua má aplicação e ainda, no caso da França, aos males advindos da influência deletéria da Igreja, cujos mosteiros e conventos provocavam a diminuição dos casamentos (pp. 192-3).

Devotava sincera admiração aos protestantes e entre esses muito especialmente aos ingleses, entre os quais a seu ver vicejavam melhor as forças do crescimento econômico, demográfico e político. Ali "vemos a liberdade nascer o tempo todo dos fogos da discórdia e da sedição; o príncipe sempre instável num trono que nada pode abalar; uma nação impaciente, sábia em meio à própria fúria e que, governando o mar (coisa até então inédita), associa comércio e império" (p. 222). Admirava nos ingleses o maior equilíbrio entre o poder dos reis e dos demais estados; a instituição judiciária e o cumprimento das leis. Acreditava que a tolerância religiosa, e a relativa igualdade existente entre eles em comparação com o que ocorria na sociedade francesa de sua época, contribuía decisivamente para uma maior harmonia entre nobres, burgueses e povos trabalhadores. Em 1715, conheceu em Paris Henry St.John Bolingbroke, político tory de oposição a Henry Walpole, exilado por sua participação na conspiração jacobita. Bolingbroke era também um ensaísta e filósofo ilustrado e partilhava com Montesquieu as qualidades mundanas de homem de salão: charmoso e mulherengo, orador excepcional, era também um conversador cativante. Suas relaçōes se estreitaram ainda mais de 1731 a 1734 , anos que Montesquieu viveu em Londres. Concordavam plenamente com a necessidade de fortalecer parlamentos para opor obstáculos aos excessos de poder dos reis.

As Cartas Persas prenunciam nesse sentido obras posteriores como o Ensaio sobre a Causa da Grandeza dos Romanos e sua Decadência (1734), onde compara os romanos aos ingleses de sua época. As cartas também já traziam em embrião as idéias fundamentais do Espírito das Leis (1750). A harmonia dos povos, para Montesquieu, se regulava pelo maior grau de liberdade reinante entre eles e esta pela 
forma dos governos, que a seu ver dependia fundamentalmente da sua capacidade de administrar as leis e de equilibrar os poderes executivo, legislativo e judiciário.

Fato é que ao publicar as Cartas Persas não hesitou em provocar a reação da Igreja e dos poderes instituídos ao afirmar por exemplo que os homens podiam sobreviver sem Deus porém nāo sem Justiça. A originalidade de sua contribuiçāo passava pela obra de Jean Bodin e certamente pela luta política dos aristocratas franceses, que no seu tempo procuravam se fortalecer enquanto magistrados do reino. "Poderíamos estar livres do jugo da religiāo, mas nunca deveríamos repudiar o jugo da eqüidade" (p. 142). De modo que podia escrever: "se existe um Deus, meu caro Rédi, necessariamente Ele tem de ser justo - porque se não o for, será o pior e mais imperfeito de todos os seres. A Justiça é uma relação de adequação entre duas coisas: essa relação jamais se altera, não importando o ser que se considere, seja Deus, seja um anjo - enfim - seja um homem" (idem, ibidem).

Do equilíbrio ou harmonia entre as relações humanas mais essenciais, ou necessárias, dependeria na verdade a sobrevivência dos povos senāo de tơda a humanidade. Havia males inerentes à natureza humana ou a certas sociedades, princípios vitais ou vícios profundos que os faziam decair lentamente até eventualmente causar-lhes o extermínio. "Nem todas as destruições são violentas: vemos várias partes da Terra que se cansam de prover à subsistência humana. Como poderemos saber se a Terra nāo tem causas de lassidāo genéricas lentas e imperceptíveis?" (p. 186). Aqui desponta a vocaçāo iconoclasta de historiador em Montesquieu, pois procura as forças atuantes no passado para exorcizá-las do futuro. "Onde mais detenho a mente é diante das enormes mudanças que fizeram as eras tão diferentes das eras, a Terra tão dessemelhante de si mesma" (p. 182). Estas diversidades foram por ele entrevistas como um processo histórico e não sob forma puramente racional. ou determinista. " A natureza age sempre com lentidão e, por assim dizer, com parcimônia: suas operaçōes jamais são violentas. Até no que produz ela requer moderaçāo. Nunca procede sem regra e medida. Se a aceleramos, ela logo se entorpece. Usa então para se conservar toda a força que lhe resta, perdendo por completo sua virtude produtiva e sua força geradora" (p. 187).

Deste modo é que divide o pensamento ilustrado, alinhando-se com os adeptos da interpretação histórica da sociedade por oposição aos partidários do direito natural, que ressaltavam a racionalidade das relações sociais e políticas (7). No que inaugurou, por oposiçāo ao racionalismo dos jusnaturalistas em geral e de Voltaire e Rousseau em particular, um dos mananciais mais moderados dentre os filosofos ilustrados. Em suas viagens pela Europa, ao visitar a Itália em 1728 tomou conhecimento com a obra de Vico então ainda um filósofo pouco conhecido, mas que teria afinidade crucial com os historistas alemães como Herder, Dilthey, assim como com a escola histórica conservadora inglesa que se identificaria, nos fins do século XVIII, com a obra de Edmund Burke.

Conceitos como o do processo temporal e do passado como força atuante nas sociedades, ou o princípio do relativismo histórico já se prenunciavam em Vico. Entretanto, Montesquieu seria um dos pioneiros deste modo de ver a natureza humana como relativa às peculiaridades do clima, da época, do tempo histórico e de um processo não necessariamente linear de evolução. " O que desejas que te diga? Verdade numa época, erro em outra" (p. 132). Os povos conheciam o progresso, mas ocasionalmente também a decadência e o retrocesso para períodos bárbaros $\mathrm{e}$ primitivos, que já teriam vivido no passado e para os quais seriam de novo arrastados. Em seu tempo preocupava-se com o processo lento de despovoamento, que discernia não somente da França, mas em toda a Terra. "... O que assinala um vício interno, um veneno secreto e escondido, uma doença que entorpece e aflige a Natureza humana" (p. 184). "...A Terra, como os outros planetas, está submetida às leis do movimento; sofre em seu interior um perpétuo combate entre seus princípios; o mar e o continente parecem travar uma guerra eterna; cada instante produz novas combinaçôes. Os homens, numa morada tão sujeita a mudanças, vivem numa condição igualmente incerta: cem mil causas podem agir, capazes de destruí-los e, com mais forte razão, de aumentar ou diminuir seu número" (p. 184).

A moderação do poder monárquico se devia aos povos nórdicos entre os quais o poder individual da nobreza guerreira limitava o arbítrio do Príncipe. Era como via as vantagens da monarquia inglesa, onde pressentia uma maior adequação das leis ao meio ambiente e ao clima, do que havia na França em sua época. Este equilíbrio provinha a seu ver principalmente da presença de um poder independente, o judi-

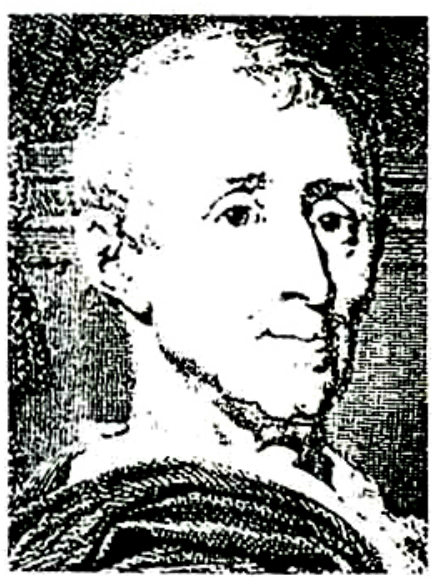

7 Albert Soboul, op. cit., p. 243. 


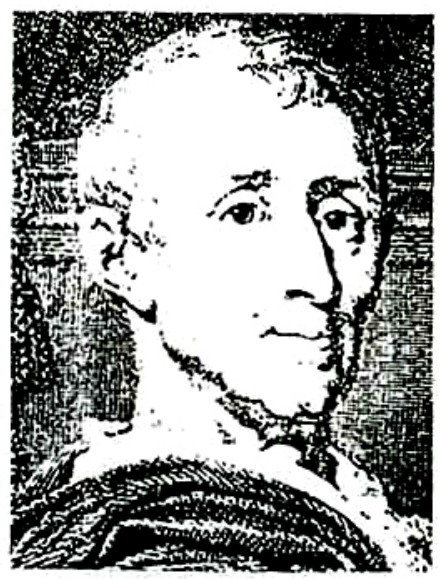

ciário, que garantia a necessária e essencial implementação das leis. Pensador original, foi mais além ao afirmar que a lei, relativa aos costumes, ao clima, não admitia uma distinção radical entre o direito público e o direito privado, pois os seus princípios básicos teriam que ser necessariamente os mesmos (p. 157).

A partir do prisma do relativismo histórico, Montesquieu delineou projetos bastante revolucionários, que inspirariam a declaração de direitos humanos dos norteamericanos e exerceriam uma decisiva influência sobre o constitucionalismo liberal dos inícios da Revolução Francesa. Tanto os girondinos, como homens de tendências diferenciadas como Marat, Mirabeau seriam discípulos fiéis ao texto de Montesquieu, como também o seriam após a Revoluçāo os restauradores monarquistas liberais constitucionais.

A tendência em geral moderada seguida mais tarde por seus adeptos nāo nos deve iludir quanto à ousadia radical das opiniōes que Montesquieu ousou expressar na primeira metade do século XVIII. Nisso aparece em sintonia com o radicalismo das opiniōes de homens também elitistas e vinculados de certa forma à aristocracia como seria mais de um século depois o caso de Tocqueville e de Burckhardt, cujas críticas anteciparam de muitos anos um diagnóstico pessimista sobre a civilização contemporânea e a cultura de massas. Por paradoxal que seja, este convívio entre alguns intelectuais de elite e o pensamento radical deu margem a críticas, visionárias, pessimistas, que ainda guardam hoje seu impacto inicial.

Outro aspecto que torna atraente na atualidade a leitura de Montesquieu provém do perspectivismo que permeia a forma e o estilo com que lapidou suas idéias. A apresentação de inúmeros pontos de vista expressos através de suas cartas e de uma multiplicidade de testemunhos e personagens nos toca de perto dentro das tendências da hermenêutica mais contemporânea. Confrontar opiniōes contrárias, exprimir verdades parciais, através das quais chegar talvez a recompor totalidades mais abrangentes, vêm de encontro às ambigüidades do pensamento crítico de fins do século XX.

Interessante, sobretudo, a contemporaneidade de muitas das observações de Montesquieu nas Cartas Persas para o leitor brasileiro. É verdade que fez críticas contundentes ao tráfico de escravos para as minas do Brasil (p. 193). Não obstante, a obra Espirito das Leis foi uma das mais assíduas nas bibliotecas coloniais brasileiras dos fins do século XVIII, tanto entre os inconfidentes mineiros - Tomás Antonio Gonzaga, em particular, foi admirador seu -, como nos depoimentos da Devassa do Rio de Janeiro, em 1794 e entre os conjurados baianos. Nenhum ilustrado foi mais citado do que ele pelos estadistas da primeira geração do Império e nos anais da Constituinte de 1823. Por ironia, suas críticas aos desmandos do poder executivo, a sua luta em prol de um judiciário forte soam atuais aos nossos ouvidos hoje. Curiosamente afins aos nossos problemas contemporâneos são os trechos em que denuncia a pobreza e o desamparo de menores na França do século XVIII: "Mas de que serve num Estado esse grande número de crianças entorpecidas pela miséria? Quase todas morrem à medida que vão nascendo; nunca se desenvolvem; fracas, débeis, morrem de mil maneiras no varejo, enquanto são levadas no atacado pelas freqüentes doenças populares, que a miséria e a má alimentação nâo param de produzir. As que sobrevivem atingem a idade viril sem a força adequada e arrastam, debilitadas, o que lhes resta de vida" (p. 199). As Cartas Persas oferecem aos olhos do leitor brasileiro a possibilidade de inúmeras leituras e também vislumbres expressivos da sua atualidade, como por exemplo o modo de Montesquieu tratar os desmandos das sucessivas políticas financeiras, principalmente a sua crítica da atuação do ministro John Law, que para nós toma um colorido familiar. "Vi outros, ainda mais indignos, comprarem por um nada, ou antes levantarem do chão folhas de carvalho (papel-moeda desvalorizado) para colocá-las no lugar da pensão das viúvas e dos órfãos" (p. 249). As passagens em que assinala a importância vital de ter leis adequadas a cada sociedade de modo a ser rigorosamente obedecidas também dão o que pensar: "Sejam quais forem as leis, devemos constantemente observá-las, considerando-as como a consciência política, à qual a dos particulares deve sempre se conformar..." (p. 210).

Quem sabe a tradução pudesse oferecer mais notas críticas situando melhor o leitor na época em que o texto foi escrito? Este senão em nada desmerece o trabalho sensível e cuidadoso do tradutor, que tornou acessível em português esta obra essencial da Ilustraçāo francesa do século das luzes. 